Document downloaded from:

http://hdl.handle.net/10251/68252

This paper must be cited as:

Conesa Domínguez, C.; Fito Suñer, PJ.; Fito Maupoey, P. (2015). EXTENSION OF THE PROJECT FOR OBTAINING BIOETHANOL FROM CITRUS WASTE. Acta Horticulturae. (1065):1693-1702. doi:10.17660/ActaHortic.2015.1065.217.

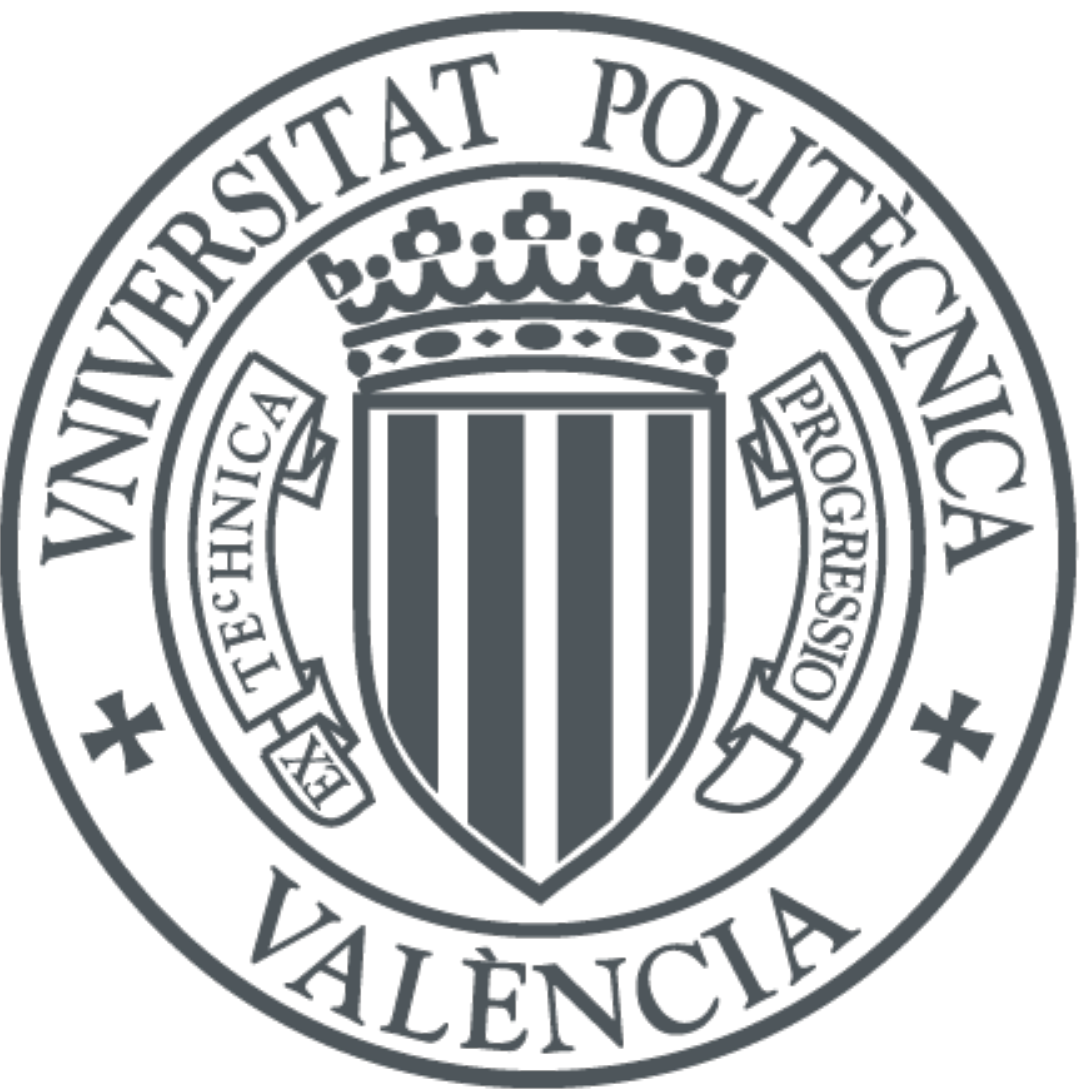

The final publication is available at

https://dx.doi.org/10.17660/ActaHortic.2015.1065.217

Copyright International Society for Horticultural Science (ISHS)

Additional Information 


\title{
Extension of the Project for Obtaining Bioethanol from Citrus Waste
}

Conesa, C.*; Fito, P.J. and Fito, P.

Instituto de Ingeniería de Alimentos para el Desarrollo (IuIAD). Universitat Politècnia de Valencia (UPV), Valencia, Spain. *clcodo@etsia.upv.es

\begin{abstract}
The production of citrus fruit in Spain generates more than $\mathbf{0 . 5}$ million tons of waste. This is mainly due to rejects when packing fresh fruit and the waste generated by processing industries. That is the reason why an important challenge for the citrus sector is the use of this waste to unlock its economic value and eliminate the environmental problems that it may generate. The Instituto de Ingeniería de Alimentos para el Desarrollo (IuIAD) at the Universitat Politècnica de Valencia (UPV) has developed a system for transforming citrus waste into bioethanol and high value-added products such as essential oils. The purpose of this study was to find the most appropriate sites to implement a bioethanol industry from citrus waste. A spreadsheet was developed from the industrial design for transforming citrus waste into bioethanol. This spreadsheet allowed us to calculate the bioethanol mass flow from a known oranges, tangerines, lemons and limes and grapefruits flow waste. Total waste of the main citrus producers was estimated as the sum of the rejects when packing fresh fruits and the wastes generated by processing industries. Total waste value (oranges, tangerines, lemons and limes and grapefruits) was multiplied by the ratio between mass flow and citrus waste flow in order to calculate the bioethanol production in each country. The results suggest that Brazil, USA, Mexico, China, India and Italy would be the most appropriate countries to implement a bioethanol industry from citrus waste.
\end{abstract}

Keywords: citrus, citrus waste, bioethanol, by-products, industrial citrus process

\section{INTRODUCTION}

The use of petroleum-based sources of energy causes both environmental and economic concerns. Energy consumption has increased considerably in recent years as the world population grows and more countries have become industrialized (Sun and Cheng, 2002). This, together with the stagnation of fossil fuel reserves, has led to rising oil prices. In addition, fossil fuels generate greenhouse gas emissions which are responsible for the climate change. As a result, the search into renewable, sustainable and environmentallyfriendly energy sources such as biomass has been encouraged. According to several authors, transportation fuels such as bioethanol or biodiesel seem to be the most suitable alternative in the short-term (Alvira et al., 2010; Sun and Cheng, 2002).

Bioethanol is a renewable fuel that can be obtained by fermenting sugar-rich, amylaceous or lignocellulosic biomass of different origin (Gonzalez-Garcia et al., 2009; Mussatto et al. 2010) However, sustainability of current production of bioethanol has become controversial due to the fact that it mostly relies on energy crops such as corn or sugarcane. This debate has caused an increasing interest in lignocellulosic biomass as an alternative for bioethanol production since it does not compete with food and it is usually less expensive than other agricultural feedstock (Alvira et al., 2010). Agricultural, 
industrial or forestry wastes are in this group and appear as a potential source for low-cost bioethanol production (Sun and Cheng, 2002).

In particular, up to $1,28 \times 10^{8}$ tons of citrus were produced worldwide in 2011 (FAOSTAT, 2011) and around 50\% of the raw material becomes waste consisting of discarded fruits, peels, seeds and segments membranes (Braddock, 1999). This is mainly due to rejects when packing fresh fruits and the waste generated by processing industries. This waste contains high concentrations of biodegradable and suspends solids which cause a serious pollution problem if they are not disposed of properly because of their high Biochemical Oxygen Demand (BOD) and Chemical Oxygen Demand (COD). However, this lignocellulosic material contains polysaccharides such as cellulose, hemicellulose and pectin, as well as several mono and disaccharides, the main ones being glucose, sucrose and fructose which are easily-fermentable by Saccharomyces cerevisiae to produce ethanol (Wilkins et al., 2007). The Institute of Food Engineering for the Development at the Polytechnic University of Valencia (Spain) has developed a system for transforming citrus waste into bioethanol, purified water, cattle feed and high valueadded products such as essential oils.

The aim of this study was to find the most appropriate sites to implement a bioethanol industry from citrus waste. For this purpose, the present study was focused on the system developed by the Institute of Food Engineering for the Development and specifically on the biofuel production line.

\section{MATERIALS AND METHODS}

\section{Developing a calculation basis for the industrial design}

First a process diagram based on the citrus by-product industrial plant designed by the IUIAD was drawn up. Then a calculation basis for oranges, mandarins, limes and lemons, and grapefruits was created considering the material and energy balances of each stage of the process.

\section{Calculation of ratios}

In order to calculate the bioethanol production ratios for each type of citrus fruit, the quotient between bioethanol mass flow output and citrus by-product inflow to the plant was calculated. Both values were obtained from the calculation basis for each citrus fruit.

\section{Calculation of total waste from major citrus-producing countries}

The waste generated by oranges, mandarins, lemons and limes and grapefruits was calculated for each of the world's twenty major citrus-producing countries. To that end we established that the waste generated by each of type citrus fruit was equal to the sum of fresh produce withdrawals and industry by-products.

Fresh produce withdrawals are due to the existence of citrus fruits that have sustained wastage due to plant diseases, pathologies or other reasons or which do not meet minimum quality standards for marketing. Since all citrus fruits behave in the same 
way, i.e. have similar respiration rates and therefore the same wastage percentages, Alfonso et al. (2010) set a ratio of 0.02 of citrus fruit withdrawn to citrus fruit produced based on a range of literature sources and checking with the industry (MARM, 2008; MARM, 2006).

To calculate the by-product generated by the industry, the amount of citrus fruit used for fresh packing was determined for each country and product. This quantity was multiplied by 0.21 for oranges, by 0.12 for mandarins and by 0.11 for the rest of citrus fruits based on Alfonso et al. (2010) criterion.

\section{Calculating the potential volume of bioethanol for each citrus-producing country}

This involved multiplying the waste mass of each citrus product by the ratio between the bioethanol outflow and the inflow of each by-product to the plant obtained from the calculation basis. The total volume of bioethanol for each citrus-producer country was obtained by adding up the total volume of bioethanol for each type of citrus fruit. Finally the countries were sorted in descending order in terms of the amount of bioethanol that could be produced.

\section{RESULTS AND DISCUSSION}

\section{Developing a calculation basis for the industrial design}

To draw up the industrial design diagram for the plant in Figure 1, both the line for the production of bioethanol from the liquid phase of the pressed citrus waste and the line for producing animal feed from the press cake were considered. Firstly, the citrus waste was mixed in a hammer mill with $0.6 \%(\mathrm{w} / \mathrm{w})$ of $\mathrm{Ca}(\mathrm{OH})_{2}$ to enable double pressing with a hammer press. The resulting solid phase was dried to obtain pellets while the liquid phases from the first and second pressing were mixed in a third tank and water, nutrients, sulphuric acid, steam and $S$. cerevisiae were added. The final mixture fermented for 50 hours at $30^{\circ} \mathrm{C}$. The fermented product was diverted into a first and a second distiller at atmospheric pressure using indirect steam from which bioethanol at $80 \%(\mathrm{v} / \mathrm{v})$ and vinasse and bioethanol at $96 \%(\mathrm{v} / \mathrm{v})$ and water were obtained respectively. The vinasse was concentrated to $45^{\circ}$ Brix in a WHE (Waste Heat Evaporator). The concentrate was collected in a storage tank from where it was pumped to the cake before the first and second pressing to make them easier.

\section{[Position of fig 1]}

To calculate the mass flow rate of bioethanol at $96 \%$ (v/v) from each citrus waste, the concurrent design of all the equipment was integrated in a single calculation basis considering the material and energy balances found at each stage. In addition the industrial plant was designed to process 35 tonnes of citrus waste per hour. Finally, the calculation bases were developed considering all these premises and the physicochemical characteristics of each waste, i.e. its fermentable and non-fermentable soluble solids, insoluble solids and water content. Figure 2 shows the calculation basis of orange waste 
in which known flow and composition data were entered in the shaded boxes. The uncoloured boxes were for the composition and mass flow rate data of each of the products in the process stages obtained from the material and energy balances.

\section{[Position of table 1]}

\section{Calculation of ratios}

Table 2 summarized the ratios between the bioethanol mass flow rate obtained for each of the citrus wastes using the calculation basis and the waste input mass flow rate to the plant.

\section{[Position of table 2]}

\section{Calculation of total waste from major citrus-producing countries}

Table 3 summarized the tonnes of oranges produced and by-products generated by the industry together with fruit wastage for the 20 major orange-producer countries in 2011 (FAOSTAT, 2011). It was found that the amount of available waste is very high in countries such as Brazil and USA, which both produce large quantities and have major juice industries (USDA, 2010). Other countries such as India, Mexico and Italy also had higher available waste than Spain, which in the case of Italy was also due to its large processing industry (ISTAT, 2010; MARM, 2010; USDA, 2010). Finally other countries with less available waste than Spain such as China, Indonesia and South Africa also topped 100.000 tonnes per year.

\section{[Position of table 3]}

The production and processing values for the major mandarin producer countries in 2010 (FAOSTAT, 2011) were shown in table 4. It was found that, in general, these figures are lower than those for oranges (FAOSTAT, 2011) and hence there is less available waste. Furthermore only China had considerably more available waste than Spain due its higher production. Behind Spain with lower waste figures were Mexico, Brazil, Japan, Turkey and Egypt, all with more than 20.000 tonnes of mandarin waste.

\section{[Position of table 4]}

Table 5 summarized the production (FAOSTAT, 2011), processing and total amount of waste values for lemons and limes in 2011. Here Argentina, Mexico and the USA were significantly ahead due to their high production (FAOSTAT, 2011) and the size of their processing industries (USDA, 2010), while India also recorded high volumes due to its large production (FAOSTAT, 2011).

\section{[Position of table 5]}


Finally grapefruit production (FAOSTAST, 2011), processing and total waste values for 2011 were shown in table 6. In this case the USA was in the lead due to its major processing industry, followed by China, Mexico and South Africa (USDA, 2010).

\section{[Position of table 6]}

\section{Calculating the potential volume of bioethanol for each citrus-producing country}

Table 7 summarized total potential bioethanol production from each type of citrus fruit waste and the total. Both Brazil at more than 164.106 litres per year and the USA with over 87.106 litres per year far exceeded Spain's potential for producing bioethanol from citrus waste. Other countries such as Mexico, China and India, albeit with potential bioethanol figures lower than Spain's, might be potential candidates for setting up bioethanol production from citrus waste. Other countries such as Argentina, South Africa, Italy, Greece, Egypt, Indonesia, Turkey, Iran and Pakistan have less potential for producing bioethanol from citrus waste, but all of them exceeded 3.000 litres per year of bioethanol. Finally Peru, Syria, Cuba, Colombia and Thailand are countries whose potential bioethanol production from citrus waste was greater than 1.000 litres per year.

\section{[Position of table 7]}

\section{CONCLUSIONS}

Brazil and the USA would be the most appropriate countries to implement a bioethanol industry from citrus waste because of their big citrus production and their strong orange juice industry.

Mexico, China, India and Italy would be strong candidates to implement a bioethanol industry with an estimate production between $10 \times 10^{6}$ and $17 \times 10^{6} 1 /$ year. Most of the bioethanol production would be from oranges except in China because of the big processing industry cannery and juice and production of tangerines.

Argentina, South Africa, Greece, Egypt, Indonesia, Turkey, Iran and Pakistan would have an estimated lower bioethanol production between $3 \times 10^{6}$ and $7 \times 10^{6} 1 /$ year. Most of bioethanol production would be from oranges except in Aregentina because of her lemons and limes industry.

Peru, Syria, Cuba, Colombia and Thailand would be minor candidates to implement a bioethanol industry from citrus waste because of their lower production and processing industry.

\section{LITERATURE CITED}

Alfonso, D.; Brines, N.; Peñalvo, E.; Vargas, C.A.; Pérez-Navarro, A.; Gómez, P.; Pascual, A.; Ruiz, B. 2010. Cuantificación de materias primas alimentarias de origen vegetal. PSE PROBIOGAS. Desarrollo de sistemas sostenibles de producción y uso de biogás agroindustrial en España. Ministerio de Ciencia e Innovación. Gobierno de España. 
Alvira, P.; Tomás-Pejó, E.; Ballesteros, M.; Negro, M.J. 2010. Pretreatment technologies for an efficient bioethanol production process based on enzymatic hydrolysis: A review. Bioresource Technology, 101: 4851-4861.

Braddock, R.J. 1999. Handbook of Citrus By-products Processing Technology. John Wiley and Sons, New York.

FAOSTAT. 2011. Food Agriculture Organization of the United Nations (FAO). www.faostat.com

Gonzalez-Garcia, S.; Gasol, C.M., Gabarell, X.; Rieradevall, J.; Moreira, T.; Feijoo, G. 2009. Environmental aspects of etanol-based fuels from Brassica carinata: A case study of second generation ethanol. Renewable and Sustainable Energy Reviews, 13: 2613-2620.

ISTAT, 2010. Chapter 3: Agricoltora.p. 336-372. In: Annuario statistico italiano. Instituto nazionale di stadistica. Roma, 2010.

Ministerio de Medio Ambiente y Medio Rural y Marino (MARM). 2006. Guía de Mejores Técnicas Disponibles en España para el sector de Transformados Vegetales.

Ministerio de Medio Ambiente y Medio Rural y Marino (MARM). 2008. Estudio de la cadena de valor y formación de precios de cítricos. Observatorio de Precios de los Alimentos.

Ministerio de Medio Ambiente y Medio Rural y Marino (MARM). 2010. Anuario de estadística. Madrid, 2010.

Mussatto, S.I.; Dragone, G., Guimaraes, P.M.R.; Silva, J.P.A., Carneiro, L.M.; Roberto, I.C.; Vicente, A.; Domingues, L.; Teixeira, J.A. 2010. Technological trends, global market, and challenges of bio-ethanol production. Biotechnology Advances, 28: 1873-1899.

Sun, Y. and Cheng, J. 2002. Hydrolysis of lignocellulosic materials for ethanol production: a review. Bioresource Technology, 83: 1-11.

United States Department of Agriculture (USDA). 2010. Foreing Agricultural Service. Citrus: World markets and Trade.

Wilkins, M. R.; Widmer, W.W.; Grohmann, K.; Cameron, R.G. 2007. Hydrolysis of grapefruit waste with cellulose and pectinase enzymes. Bioresource Technology 97: 1596-1601 


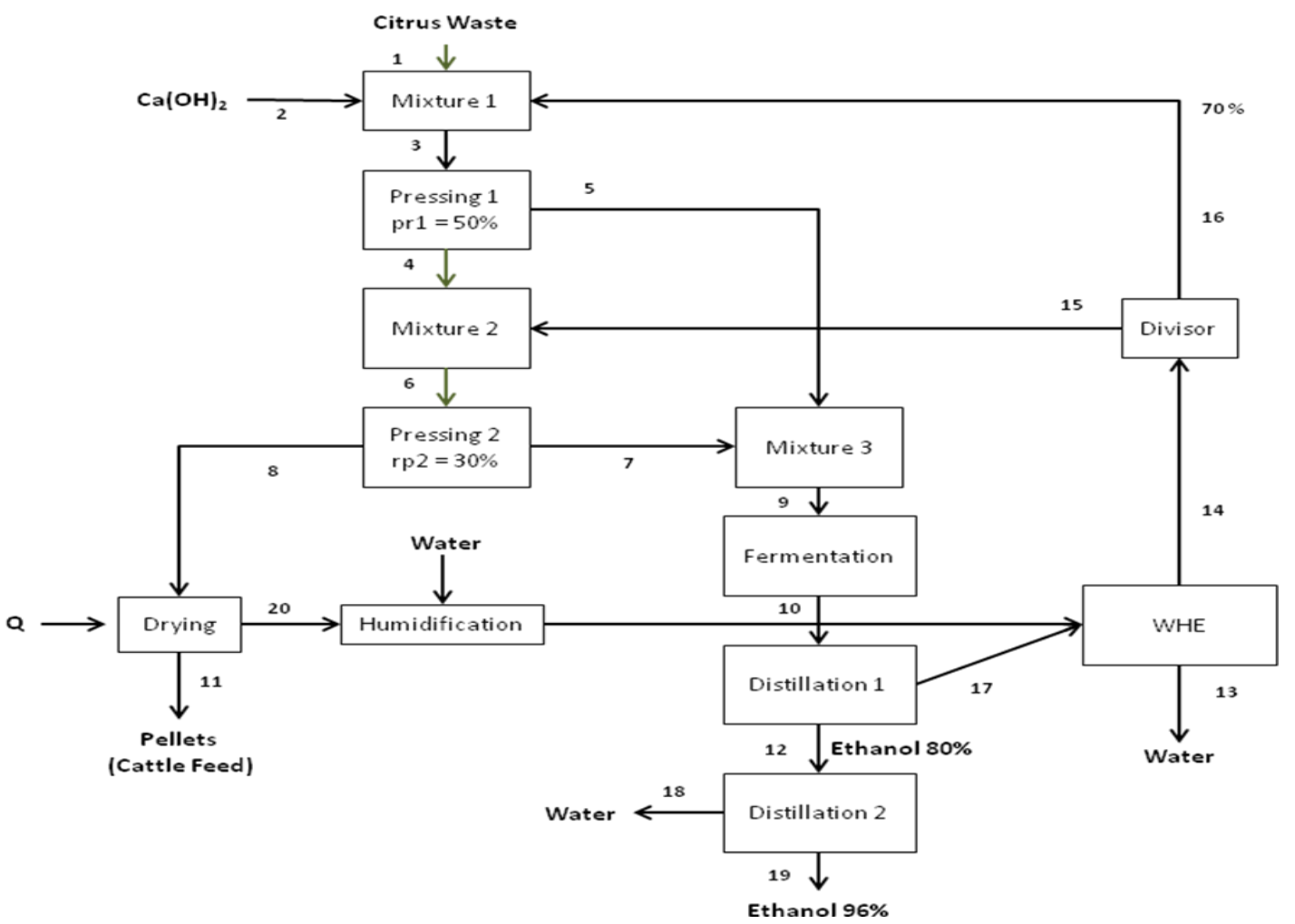

Figure 1. - Flow diagram of the industrial plant design for obtaining bioethanol from citrus waste.

Table 1. - Spreadsheet of the industrial plant design for obtaining bioethanol from orange waste.

\begin{tabular}{|c|c|c|c|c|c|c|c|c|}
\hline Stream & $\begin{array}{c}\text { Flow } \\
\mathbf{M} \\
\mathbf{k g} / \mathbf{h})\end{array}$ & $\begin{array}{c}\text { Water } \\
\mathbf{x}_{\mathbf{w}}\end{array}$ & $\begin{array}{c}\mathbf{C a}(\mathbf{O H}) \mathbf{2} \\
\mathbf{x}_{\mathbf{C a}}\end{array}$ & $\begin{array}{c}\text { Fermentable } \\
\text { Soluble Solids } \\
\mathbf{x}_{\mathbf{s f}}\end{array}$ & $\begin{array}{c}\text { Non } \\
\text { Fermentable } \\
\text { Soluble Solids } \\
\mathbf{x}_{\mathbf{s n}}\end{array}$ & $\begin{array}{c}\text { Ethanol } \\
\mathbf{x}_{\mathbf{E}}\end{array}$ & $\begin{array}{c}\text { Insoluble } \\
\text { solids } \\
\mathbf{x}_{\mathbf{s i}}\end{array}$ & $\begin{array}{c}\text { SST } \\
\mathbf{Z}_{\mathbf{s s}} \\
(\mathbf{B r i x})\end{array}$ \\
\hline $\mathbf{1}$ & 35.000 & 0,87 & 0 & 0,08176 & 0,0302 & 0 & 0,018 & 11,4 \\
\hline $\mathbf{2}$ & 140 & 0,08 & 0,92 & 0 & 0 & 0 & 0 & 0,0 \\
\hline $\mathbf{3}$ & 37.608 & 0,8461 & 0,0034 & 0,07609 & 0,0577 & 0 & 0,017 & 13,7 \\
\hline $\mathbf{4}$ & 18.804 & 0,8286 & 0,0068 & 0,07452 & 0,0565 & 0 & 0,034 & 13,7 \\
\hline $\mathbf{5}$ & 18.804 & 0,8635 & 0 & 0,07766 & 0,0589 & 0 & 0 & 13,7 \\
\hline $\mathbf{6}$ & 19.862 & 0,8138 & 0,0065 & 0,07055 & 0,0774 & 0 & 0,032 & 15,4 \\
\hline $\mathbf{7}$ & $5.958,5$ & 0,8461 & 0 & 0,07336 & 0,0805 & 0 & 0 & 15,4 \\
\hline $\mathbf{8}$ & 13.903 & 0,7999 & 0,0093 & 0,06935 & 0,0761 & 0 & 0,045 & 15,4 \\
\hline $\mathbf{9}$ & 24.763 & 0,8593 & 0 & 0,07662 & 0,0641 & 0 & 0 & 14,1 \\
\hline $\mathbf{1 0}$ & 23.886 & 0,8908 & 0 & 0 & 0,0664 & 0,043 & 0 & 6,9 \\
\hline $\mathbf{1 1}$ & $3.090,5$ & 0,1 & 0,0417 & 0,312 & 0,3425 & 0 & 0,204 & 86,7 \\
\hline $\mathbf{1 2}$ & 1.276 & 0,2 & 0 & 0 & 0 & 0,8 & 0 & 0,0 \\
\hline $\mathbf{1 3}$ & 19.084 & 1 & 0 & 0 & 0 & 0 & 0 & 0,0 \\
\hline $\mathbf{1 4}$ & $3.525,9$ & 0,55 & 0 & 0 & 0,45 & 0 & 0 & 45,0 \\
\hline $\mathbf{1 5}$ & $1.057,8$ & 0,55 & 0 & 0 & 0,45 & 0 & 0 & 45,0 \\
\hline $\mathbf{1 6}$ & $2.468,1$ & 0,55 & 0 & 0 & 0,45 & 0 & 0 & 45,0 \\
\hline $\mathbf{1 7}$ & 22.610 & 0,9298 & 0 & 0 & 0,0702 & 0 & 0 & 7,0 \\
\hline $\mathbf{1 8}$ & 212,67 & 1 & 0 & 0 & 0 & 0 & 0 & 0,0 \\
\hline $\mathbf{1 9}$ & $1.063,3$ & 0,04 & 0 & 0 & 0 & 0,96 & 0 & 0,0 \\
\hline $\mathbf{2 0}$ & 10.813 & 1 & 0 & 0 & 0 & 0 & 0 & 0,0 \\
\hline
\end{tabular}


Table 2. - Ratio between the bioethanol mass flow and the citrus waste mass flow.

\begin{tabular}{|c|c|}
\hline $\mathbf{r}_{\text {bioethanol-orange waste }}(\mathbf{w} / \mathbf{w})$ & 0,030 \\
\hline $\mathbf{r}_{\text {bioethanol-tangerine waste }}(\mathbf{w} / \mathbf{w})$ & 0,029 \\
\hline $\mathbf{r}_{\text {bioethanol- lemon and lime waste }}(\mathbf{w} / \mathbf{w})$ & 0,014 \\
\hline $\mathbf{r}_{\text {bioethanol-grapefruit waste }}(\mathbf{w} / \mathbf{w})$ & 0,019 \\
\hline
\end{tabular}

Table 3- Main orange producers and their total orange waste.

\begin{tabular}{|c|c|c|c|c|c|c|}
\hline Rank & Country & Production $(t)^{(1)}$ & Industry (t) & Industrial waste (t) & Rejects (t) & Total waste(t) \\
\hline 1 & Brazil & 18.101 .700 & $12.158 .000^{(4)}$ & 3.890 .560 & 362.034 & 4.252 .594 \\
\hline 2 & United States & 7.974 .000 & $6.183 .000^{(4)}$ & 1.978 .560 & 159.480 & 2.138 .040 \\
\hline 3 & India & 6.268 .100 & $658.151^{(4)}$ & 210.608 & 125.362 & 335.970 \\
\hline 4 & China & 5.500 .000 & $180.000^{(4)}$ & 57.600 & 110.000 & 167.600 \\
\hline 5 & Mexico & 4.100 .000 & $850.000^{(4)}$ & 272.000 & 82.000 & 354.000 \\
\hline 6 & Egypt & 3.645 .000 & $75.000^{(4)}$ & 24.000 & 72.900 & 96.900 \\
\hline 7 & Spain & 2.669 .355 & $500.342^{(3)}$ & 160.109 & 53.387 & 213.497 \\
\hline 8 & Italy & 2.393 .660 & $1.436 .196^{(2)}$ & 459.583 & 47.873 & 507.456 \\
\hline 9 & Indonesia & 2.032 .670 & $213.430^{(4)}$ & 68.298 & 40.653 & 108.951 \\
\hline 10 & Turkey & 1.710 .000 & $100.000^{(4)}$ & 32.000 & 34.200 & 66.200 \\
\hline 11 & Pakistan & 1.505 .000 & $158.685^{(4)}$ & 50.779 & 30.100 & 80.879 \\
\hline 12 & Iran & 1.502 .820 & $158.455^{(4)}$ & 50.706 & 30.056 & 80.762 \\
\hline 13 & South Africa & 1.414 .590 & $243.133^{(4)}$ & 77.802 & 28.292 & 106.094 \\
\hline 14 & Morocco & 849.197 & $6.252^{(4)}$ & 2.001 & 16.984 & 18.985 \\
\hline 15 & Argentina & 833.486 & $189.519^{(4)}$ & 60.646 & 16.670 & 77.316 \\
\hline 16 & Greece & 770.000 & $176.845^{(4)}$ & 56.590 & 15.400 & 71.990 \\
\hline 17 & Algeria & 740.000 & $37.873^{(4)}$ & 12.119 & 14.800 & 26.919 \\
\hline 18 & Vietnam & 729.400 & $0^{(4)}$ & 0 & 14.588 & 14.588 \\
\hline 19 & Syria & 668.900 & $65.027^{(4)}$ & 20.809 & 13.378 & 34.187 \\
\hline 20 & Ghana & 556.100 & $28.461^{(4)}$ & 9.107 & 11.122 & 20.229 \\
\hline
\end{tabular}

Sources: ${ }^{(1)}$ FAOSTAT, 2011; ${ }^{(2)}$ ISTAT, 2010; ${ }^{(3)}$ MARM, 2010; ${ }^{(4)}$ USDA, 2010.

Table 4- Main tangerine producers and their total tangerine waste.

\begin{tabular}{|r|r|r|r|r|r|r|}
\hline Rank & Country & Production (t) & Industry $(\mathbf{t})$ & Industrial waste (t) & Rejects (t) & Total waste(t) \\
\hline $\mathbf{1}$ & China & 10.142 .430 & $420.000^{(4)}$ & 29.400 & 202.849 & 232.249 \\
\hline $\mathbf{2}$ & Spain & 1.708 .200 & $203.407^{(3)}$ & 14.238 & 34.164 & 48.402 \\
\hline $\mathbf{3}$ & Brazil & 1.122 .730 & $51.646^{(4)}$ & 3.615 & 22.455 & 26.070 \\
\hline $\mathbf{4}$ & Turkey & 858.699 & $65.261^{(4)}$ & 4.568 & 17.174 & 21.742 \\
\hline $\mathbf{5}$ & Egypt & 796.867 & $60.562^{(4)}$ & 4.239 & 15.937 & 20.177 \\
\hline $\mathbf{6}$ & Japan & 786.000 & $94.000^{(4)}$ & 6.580 & 15.720 & 22.300 \\
\hline $\mathbf{7}$ & South Korea & 614.871 & $85.000^{(4)}$ & 5.950 & 12.297 & 18.247 \\
\hline $\mathbf{8}$ & Pakistan & 559.000 & $49.849^{(4)}$ & 3.489 & 11.180 & 14.669 \\
\hline $\mathbf{9}$ & United States & 540.682 & $159.000^{(4)}$ & 11.130 & 10.814 & 21.944 \\
\hline $\mathbf{1 0}$ & Morocco & 472.834 & $0^{(4)}$ & 0 & 9.457 & 9.457 \\
\hline $\mathbf{1 1}$ & Argentina & 423.737 & $80.166^{(4)}$ & 5.612 & 8.475 & 14.086 \\
\hline
\end{tabular}




\begin{tabular}{|r|r|r|r|r|r|r|}
\hline $\mathbf{1 2}$ & Mexico & 409.442 & $265.682^{(4)}$ & 18.598 & 8.189 & 26.787 \\
\hline $\mathbf{1 3}$ & Thailand & 280.190 & $24.986^{(4)}$ & 1.749 & 5.604 & 7.353 \\
\hline $\mathbf{1 4}$ & Iran & 276.138 & $24.625^{(4)}$ & 1.724 & 5.523 & 7.246 \\
\hline $\mathbf{1 5}$ & Italy & 240.628 & $29.242^{(2)}$ & 2.047 & 4.813 & 6.859 \\
\hline $\mathbf{1 6}$ & Peru & 221.324 & $10.128^{(4)}$ & 709 & 4.426 & 5.135 \\
\hline $\mathbf{1 7}$ & Algeria & 185.800 & $0^{(4)}$ & 0 & 3.716 & 3.716 \\
\hline $\mathbf{1 8}$ & Nepal & 174.867 & $0^{(4)}$ & 0 & 3.497 & 3.497 \\
\hline $\mathbf{1 9}$ & Israel & 152.207 & $35.515^{(4)}$ & 2.486 & 3.044 & 5.530 \\
\hline $\mathbf{2 0}$ & South Africa & 142.500 & $0^{(4)}$ & 0 & 2.850 & 2.850 \\
\hline
\end{tabular}

Sources: ${ }^{(1)}$ FAOSTAT, 2011; ${ }^{(2)}$ ISTAT, 2010; ${ }^{(3)}$ MARM, 2010; ${ }^{(4)}$ USDA, 2010.

Table 5- Main lemon and lime producers and their lemon and limes total waste.

\begin{tabular}{|c|c|c|c|c|c|c|}
\hline Rank & Country & Production $(t)^{(1)}$ & Industry (t) & Industrial waste (t) & Rejects (t) & Total waste(t) \\
\hline 1 & India & 3.098 .900 & $153.819^{(4)}$ & 24.611 & 61.978 & 86.589 \\
\hline 2 & Mexico & 1.880 .000 & $305.000^{(4)}$ & 48.800 & 37.600 & 86.400 \\
\hline 3 & Argentina & 1.300 .000 & $973.000^{(4)}$ & 155.680 & 26.000 & 181.680 \\
\hline 4 & China & 1.058 .105 & $52.521^{(4)}$ & 8.403 & 21.162 & 29.565 \\
\hline 5 & Brazil & 1.020 .350 & $92.243^{(4)}$ & 14.759 & 20.407 & 35.166 \\
\hline 6 & United States & 853.000 & $355.000^{(4)}$ & 56.800 & 17.060 & 73.860 \\
\hline 7 & Turkey & 782.000 & $60.000^{(4)}$ & 9.600 & 15.640 & 25.240 \\
\hline 8 & Iran & 706.800 & $35.083^{(4)}$ & 5.613 & 14.136 & 19.749 \\
\hline 9 & Spain & 558.180 & $68.301^{(3)}$ & 10.928 & 11.164 & 22.092 \\
\hline 10 & Italy & 522.377 & $73.133^{(2)}$ & 11.701 & 10.448 & 22.149 \\
\hline 11 & Egypt & 318.111 & $0^{(4)}$ & 0 & 6.362 & 6.362 \\
\hline 12 & Peru & 233.032 & $21.067^{(4)}$ & 3.371 & 4.661 & 8.031 \\
\hline 13 & Sudan & 228.000 & $0^{(4)}$ & 0 & 4.560 & 4.560 \\
\hline 14 & South Africa & 215.985 & $5.400^{(4)}$ & 864 & 4.320 & 5.184 \\
\hline 15 & Thailand & 171.074 & $8.492^{(4)}$ & 1.359 & 3.421 & 4.780 \\
\hline 16 & Chile & 155.000 & $14.013^{(4)}$ & 2.242 & 3.100 & 5.342 \\
\hline 17 & Syria & 142.200 & $12.225^{(4)}$ & 1.956 & 2.844 & 4.800 \\
\hline 18 & Lebanon & 113.100 & $9.724^{(4)}$ & 1.556 & 2.262 & 3.818 \\
\hline 19 & Guatemala & 107.796 & $9.745^{(4)}$ & 1.559 & 2.156 & 3.715 \\
\hline 20 & Colombia & 87.474 & $7.908^{(4)}$ & 1.265 & 1.749 & 3.015 \\
\hline
\end{tabular}

Sources: ${ }^{(1)}$ FAOSTAT, 2011; ${ }^{(2)}$ ISTAT, 2010; ${ }^{(3)}$ MARM, 2010; ${ }^{(4)}$ USDA, 2010.

Table 6- Main grapefruit producers and their grapefruit total waste.

\begin{tabular}{|c|c|c|c|c|c|c|}
\hline Rank & Country & Production $(t)^{(1)}$ & Industry (t) & Industrial waste (t) & Rejects (t) & Total waste(t) \\
\hline 1 & China & 2.600 .000 & $0^{(4)}$ & 0 & 52.000 & 52.000 \\
\hline 2 & United States & 1.090 .000 & $520.000^{(4)}$ & 114.400 & 21.800 & 136.200 \\
\hline 3 & Mexico & 430.000 & $100.000^{(4)}$ & 22.000 & 8.600 & 30.600 \\
\hline 4 & South Africa & 370.000 & $167.000^{(4)}$ & 36.740 & 7.400 & 44.140 \\
\hline 5 & Thailand & 294.949 & $0^{(4)}$ & 0 & 5.899 & 5.899 \\
\hline 6 & India & 260.300 & $0^{(4)}$ & 0 & 5.206 & 5.206 \\
\hline
\end{tabular}




\begin{tabular}{|r|r|r|r|r|r|r|}
\hline $\mathbf{7}$ & Israel & 225.000 & $104.000^{(4)}$ & 22.880 & 4.500 & 27.380 \\
\hline $\mathbf{8}$ & Turkey & 210.000 & $2.376^{(4)}$ & 523 & 4.200 & 4.723 \\
\hline $\mathbf{9}$ & Cuba & 137.660 & $121.967^{(4)}$ & 26.833 & 2.753 & 29.586 \\
\hline $\mathbf{1 0}$ & Argentina & 130.000 & $62.000^{(4)}$ & 13.640 & 2.600 & 16.240 \\
\hline $\mathbf{1 1}$ & Tunisia & 89.800 & $0^{(4)}$ & 0 & 1.796 & 1.796 \\
\hline $\mathbf{1 2}$ & Brazil & 72.100 & $5.382^{(4)}$ & 1.184 & 1.442 & 2.626 \\
\hline $\mathbf{1 3}$ & Bangladesh & 58.468 & $0^{(4)}$ & 0 & 1.169 & 1.169 \\
\hline $\mathbf{1 4}$ & Iran & 46.500 & $0^{(4)}$ & 0 & 930 & 930 \\
\hline $\mathbf{1 5}$ & Paraguay & 44.000 & $3.285^{(4)}$ & 723 & 880 & 1.603 \\
\hline $\mathbf{1 6}$ & Spain & 43.200 & $2.512^{(3)}$ & 553 & 864 & 1.417 \\
\hline $\mathbf{1 7}$ & Swaziland & 37.000 & $0^{(4)}$ & 0 & 740 & 740 \\
\hline $\mathbf{1 8}$ & Belize & 36.000 & $2.688^{(4)}$ & 591 & 720 & 1.311 \\
\hline $\mathbf{1 9}$ & Philippines & 33.472 & $0^{(4)}$ & 0 & 669 & 669 \\
\hline $\mathbf{2 0}$ & Italy & 7.125 & $414^{(2)}$ & 91 & 143 & 234 \\
\hline
\end{tabular}

Sources: ${ }^{(1)}$ FAOSTAT, 2011; ${ }^{(2)}$ ISTAT, 2010; ${ }^{(3)}$ MARM, 2010; ${ }^{(4)}$ USDA, 2010.

Table 7. World's main bioethanol producers from orange, tangerine, lemon and lime and grapefruit waste.

\begin{tabular}{|c|c|c|c|c|c|c|}
\hline Rank & Country & $\begin{array}{c}\text { Total } \\
\text { Bioethanol } \\
\text { (l/year) }\end{array}$ & $\begin{array}{c}\text { Bioethanol } \\
\text { from orange } \\
\text { (l/year) }\end{array}$ & $\begin{array}{l}\text { Bioethanol } \\
\text { from } \\
\text { tangerine } \\
\text { (l/year) }\end{array}$ & $\begin{array}{c}\text { Bioethanol from } \\
\text { lemon and lime } \\
\text { (1/year) }\end{array}$ & $\begin{array}{l}\text { Bioethanol } \\
\text { from } \\
\text { grapefruit } \\
\text { (l/year) }\end{array}$ \\
\hline 1 & Brazil & 164.331 .569 & 162.718 .262 & 952.000 & 598.780 & 62.527 \\
\hline 2 & United States & 87.110 .451 & 81.808 .457 & 801.331 & 1.257 .632 & 3.243 .032 \\
\hline 3 & Spain & 20.050 .118 & 19.416 .939 & 250.471 & 377.136 & 5.572 \\
\hline 4 & China & 16.723 .153 & 13.545 .207 & 978.183 & 1.471 .153 & 728.611 \\
\hline 5 & Mexico & 16.635 .553 & 6.412 .928 & 8.481 .053 & 503.410 & 1.238 .162 \\
\hline 6 & India & 14.453 .650 & 12.855 .319 & 0 & 1.474 .371 & 123.959 \\
\hline 7 & Italy & 10.346 .504 & 8.169 .099 & 1.767 .499 & 376.166 & 33.740 \\
\hline 8 & Argentina & 6.952 .940 & 2.958 .365 & 514.379 & 3.093 .508 & 386.688 \\
\hline 9 & South Africa & 5.302 .858 & 4.059 .506 & 104.074 & 88.269 & 1.051 .009 \\
\hline 10 & Egypt & 4.553 .917 & 3.707 .713 & 736.805 & 108.327 & 1.071 \\
\hline 11 & Turkey & 4.168 .824 & 4.168 .824 & 0 & 0 & 0 \\
\hline 12 & Iran & 3.869 .210 & 2.533 .030 & 793.954 & 429.767 & 112.458 \\
\hline 13 & Pakistan & 3.713 .238 & 3.090 .220 & 264.603 & 336.271 & 22.144 \\
\hline 14 & Greece & 3.671 .282 & 3.094 .697 & 535.669 & 40.916 & 0 \\
\hline 15 & Indonesia & 2.994 .931 & 2.754 .575 & 135.332 & 54.283 & 50.741 \\
\hline 16 & Peru & 1.508 .042 & 1.308 .107 & 34.509 & 81.731 & 83.695 \\
\hline 17 & Cuba & 1.190 .505 & 1.030 .010 & 135.697 & 24.179 & 619 \\
\hline 18 & Colombia & 1.094 .225 & 202.222 & 201.939 & 38.124 & 651.940 \\
\hline 19 & Syria & 1.079 .909 & 726.429 & 345.342 & 7.662 & 476 \\
\hline 20 & Thailand & 895.820 & 60.035 & 814.331 & 21.454 & 0 \\
\hline
\end{tabular}

